\title{
COMPLIANCE WITH INTERNATIONAL FINANCIAL REPORTING STANDARDS (IFRSs) IN A DEVELOPING COUNTRY: EVIDENCE FROM MALAYSIA
}

\author{
Mazni Abdullah ${ }^{1}$, Noor Adwa Sulaiman, Kamisah Ismail and \\ Noor Sharoja Sapiei
}

\begin{abstract}
There are three objectives of this study; first, to examine the level of compliance with the requirements of IFRS disclosure of Malaysian corporations; second, to identify which IFRS are problematic to comply with by the majority of Malaysian corporations; and, third, to understand why Malaysian corporations have difficulty in complying with the identified problematic IFRS. To achieve these objectives, we examine the annual reports of public listed companies and interview the accounting practitioners. Our results show that none of the examined companies fully complies with the requirements of IFRS disclosure. In addition, three IFRS are identified as problematic - accounting standards on impairment of assets, leases and employee benefits. Overall, this study demonstrates that the mere adoption of IFRS does not necessarily mean that the financial reports are transparent.
\end{abstract}

Keywords: Compliance, IFRS, Disclosures, Annual Reports, Interviews

\section{Introduction.}

The adoption of International Financial Reporting Standards (IFRS) by countries around the world has been of interest to many parties, such as policymakers, regulators, investors and researchers. It is argued that IFRS offers more benefit compared to the national accounting standards in terms of transparency and comparability of financial reporting, eliminates cross-border investing barriers, increases market efficiency and decreases the cost of capital (Brown, 2011). Barth et al. (2008) also demonstrate that companies that have adopted IFRS exhibit less earnings management, more timely loss recognition and more value relevance

Corresponding author: Dr Mazni Abdullah is a Senior Lecturer at the Faculty of Business and Accountancy, University of Malaya, email: mazni@um.edu.my. Other co-authors are also Senior Lecturer at the Faculty of Business and Accountancy, University of Malaya. 
than companies that did not adopt IFRS. Similarly, they find that companies adopting IFRS have shown an improvement between the pre- and post-adoption periods. Nevertheless, these benefits cannot be achieved if the companies do not comply with the standards. Therefore, researchers argue that compliance with the standards is as important as the standards themselves (Hodgdon et al., 2009).

Despite the importance of compliance with IFRS, a number of studies demonstrated that companies that claim full compliance with IFRS are, in fact, not fully compliant with IFRS (e.g. Street and Bryant, 2000; Street and Gray, 2002). More worryingly, these companies have received a clean audit report from auditors despite their significant non-compliance with IFRS (e.g. Cairns, 2001). Researchers also argue that the level of disclosure by emerging and developing countries lags behind developed countries, and the government regulatory bodies often take a lenient approach in enforcing the existing accounting regulations (e.g. Ali et al., 2004; Saudagaran, 2001).

Given this contentious issue, this study aims to examine compliance with IFRS in a developing country, and choose Malaysia as the context of the study for two reasons. First, although there is an abundance of literature on compliance with IFRS, little is known about compliance with IFRS in Malaysia. Therefore, by documenting the evidence of compliance with IFRS by Malaysian corporations, this study will contribute to the extant literature on compliance or mandatory disclosure. Second, in 2008, the Malaysian government planned to achieve full convergence with IFRS by 1 January $2012 ;^{2}$ therefore, the findings of this study might be of interest to various parties, such as regulators and investors, about the current status of compliance with IFRS in Malaysia and the problems of compliance by Malaysian corporations. Specifically, this study outlines its three objectives: (1) to examine the level of compliance with IFRS disclosure requirements by Malaysian corporations; (2) to identify which IFRS are problematic to comply with by the majority of Malaysian corporations; and (3) to know the reasons why Malaysian corporations have difficulty in complying with these problematic IFRS.

This paper is arranged as follows. Section 2 provides a literature review on compliance with IFRS. Section 3 describes the research methods. Section 4 discusses the findings of the study. Section 5 concludes the study.

\section{Literature Review}

Studies on compliance with IFRS show that there is significant non-compliance with IFRS in many aspects (e.g. Street et al., 1999; Cairns, 2001; Street and Gray, 2002). These studies also document a number of problematic IFRS that are difficult to comply with. For example, Street et al. (1999), in their study of 49 major companies from 12 countries, observe that the main areas of

\footnotetext{
An effort to converge with IFRS in Malaysia started in 2006, in that the Financial Reporting Standards (FRS) have been made identical to IFRS on a per standard basis.
} 
non-compliance include IAS 2 (Inventory), IAS 8 (Net profit or loss for the period), IAS 9 (Research and Development costs), IAS 16 (Property, Plant and Equipment), IAS 18 (Revenue), IAS 19 (Retirement Benefit Costs), IAS 21 (The effect of changes in foreign exchange rates), IAS 29 (Hyper inflationary economies), IAS 22 (Business combination) and IAS 23 (Borrowing costs). Street and Gray (2002) later use a larger sample size, which consists of 279 companies from 32 countries and document a number of problematic accounting standards - IAS 12, IAS 14, IAS 16, IAS 17, IAS 19, IAS 23, IAS 29, IAS 32 and IAS 33. In addition, they observe that none of the companies in the sample achieve 100 per cent compliance.

Cairns (2001) assesses a sample of 165 companies that used IFRS in their 1999-2000 financial statements. He observes that several companies claim that their financial statements comply with IFRS, although their accounting policies did not. He reveals that $29 \%$ of the surveyed companies follow 'implied IFRS lite', whereby companies claim to use IFRS, but, in fact, do not comply fully with IFRS. He also identifies several problematic accounting standards, which include IAS12-Income Taxes, IAS14-Segment Reporting and IAS35-Discontinuing Operations. He also observes that some auditors issued unqualified audit reports for companies that did not comply with IFRS.

Glaum and Street (2003) examine the extent of compliance with both IAS and US GAAP for companies listed on Germany's New Market for the year 2000. They find that the extent of compliance for companies that applied US GAAP is significantly higher than companies that apply IFRS (86.6\% versus $80.9 \%)$. They also document that compliance with IFRS is problematic concerning disclosures associated with pensions, leasing, financial instruments, earnings per share, research and development, and provisions and contingencies.

Al-Shammari et al. (2008) examine the level of compliance with IFRS in six Gulf Co-operation Council (GCC) countries, namely, Bahrain, Kuwait, Saudi Arabia, Qatar, the United Arab Emirates (UAE) and Oman from 1996 to 2002. Their study shows that the level of compliance among these countries varies even though they have some similarities in terms of the culture and economy. They suggest that the institutional framework of a country, such as regulations and enforcement mechanisms, contribute to the differences in the level of compliance with IFRS from one country to another. Furthermore, they document that the level of compliance varies across the standards. The highest compliance level (with a mean compliance score above $80 \%$ ) was IAS 1, IAS 16, IAS 18, IAS 23, IAS 24, IAS 27 and IAS 30, whereas, the lowest compliance level (mean compliance score below 50\%) is IAS 14 and IAS 37. They argue that certain standards have a higher level of compliance because the standards are less difficult to implement and do not request more proprietary information as compared to IAS 14 and IAS 37.

A review of prior literature indicates that although these studies document problematic IFRS, none of them explore the reasons why these IFRS are problematic from the perspectives of the preparers. Therefore, the present study 
attempts to fill this gap by examining which accounting standards are problematic in Malaysia, and explores the reasons why these standards are problematic to comply with by Malaysian corporations.

\section{Research Methods}

This study employs two research methods - disclosure analysis and semistructured interviews. To achieve the first and second objectives of this study, we examine the mandatory disclosure in the annual reports of 225 Malaysian public listed companies. The companies were randomly selected from the Malaysian Stock Exchange (known as Bursa Malaysia) after excluding 41 companies from the finance industry because they are subject to different regulations. In Malaysia, the finance industry is under the supervision of the Central Bank of Malaysia. Annual reports for the year ended 2008 were downloaded from the website of Bursa Malaysia.

To achieve the third objective of the study, we interviewed financial controllers and auditors because they are involved in the preparation of financial statements in accordance with IFRS. The semi-structured interviews were conducted by one of the researchers after completing the first and second objectives of the study. Twenty-three financial controllers and eleven auditors were interviewed; however, only some of them responded to the questions because they either opted not to comment or did not have knowledge about the accounting standards. The interview sessions lasted between 60 and 90 minutes. Each interview was recorded and subsequently transcribed for review.

\subsection{Disclosure Checklist}

A self-constructed disclosure checklist was developed to measure the level of compliance with IFRS disclosure requirements. This is similar to the approach adopted by prior studies on mandatory disclosure (e.g. Ali et al., 2004; OwusuAnsah, 1998). The index items were derived from the disclosure requirements prescribed under the 12 accounting standards: (1) FRS2-Share Based Payment; (2) FRS3-Business Combination; (3) FRS5-Non-current assets held for sale and Discontinued Operations; (4) FRS101-Presentation of Financial Statements; (5) FRS114-Segment Reporting; (6) FRS116-Property, Plant and Equipment; (7) FRS117-Leases; (8) FRS119-Employee Benefits; (9) FRS132-Financial Instruments: Disclosure and Presentation; (10) FRS136-Impairment of Assets; and (11) FRS138-Intangible Assets and FRS140-Investment Property. It is important to highlight that International Financial Reporting Standards (IFRS) in Malaysia are known as Financial Reporting Standards (FRS). ${ }^{3}$ Similar to the approach used by prior studies (e.g. Tsalavoutas, 2011), the initially constructed disclosure

\footnotetext{
Effective 1 January 2012, the Financial Reporting Standards (FRS) were renamed as the Malaysian Financial Reporting Standards (MFRS). The contents of FRS or MFRS are identical with IFRS.
} 
checklist of the present study was reviewed by two chartered accountants to ensure its validity in measuring compliance with IFRS disclosure requirements. Any ambiguity raised was referred to another independent person with extensive experience of IFRS. After taking into account all the suggestions and comments from these three referees, the final disclosure checklist contained 295 items.

The reliability of the research instrument refers to the "extent to which it is without bias (error free) and hence ensures consistent measurement across time and across the various items in the instrument" (Sekaran, 2003, p.203). Thus, to ensure the reliability of the disclosure checklist, a pilot study was undertaken whereby the researcher and another independent person with IFRS knowledge examined and scored the financial statements of 12 companies. The results of the compliance scores from the researcher and the independent person were then compared and analysed. The results showed that there was substantial agreement between the scores, which indicated minimal subjectivity in the scoring process; thus, the disclosure checklist used in this study is considered reliable. ${ }^{4}$

\subsection{The Scoring Method}

The scoring process involves the subjective judgement of the researcher (Marston and Shrives, 1991), thus it is likely that a company will be penalised for nondisclosure of an item, which, in fact, is not applicable to the company (OwusuAnsah, 1998). To mitigate this problem, the present study followed the practice of prior research, in which the entire annual report was read at least twice to understand the nature and complexity of each company's operation before any decision was made (e.g. Ali et al., 2004; Owusu-Ansah, 1998;). Then the unweighted disclosure index was used to score the disclosure checklist, because, under this approach, all disclosure items were assumed to be equally important to all users of annual reports (Cooke, 1989). Owusu-Ansah (1998) also notes that the unweighted index may provide a more independent analysis because no particular user group's perceptions are involved. The most common unweighted disclosure index used in prior studies is the 'dichotomous' method, in which an item is scored one if disclosed, zero if not disclosed, or not applicable (NA) if the item is not relevant to the company (e.g. Yeoh, 2005; Glaum and Street, 2003). Under this method, a company will not be penalised for not disclosing items that are not relevant to that company (Owusu-Ansah, 1998; Cooke, 1992). The dichotomous disclosure index is computed as the ratio of the total items disclosed to the maximum possible number of items applicable to the company, which can be stated in the formula below.

$$
C S_{j}=\frac{T=\sum_{i=1}^{m} d_{i}}{M=\sum_{i=1}^{n} d_{i}}
$$

A similar approach was used by Owusu-Ansah (1998) and Yeoh (2005) to test the reliability of the scoring instrument. 
Where $\mathrm{CS}_{j}$ is the total compliance score for each company, and $0 \leq \mathrm{CS}_{j} \leq 1$; $\mathrm{T}$ is the total number of items disclosed $\left(d_{i}\right)$ by company $j$, and $m \leq n$; and $\mathrm{M}$ is the maximum number of applicable items that the company $j$ is expected to disclose, i.e. $n \leq 295$.

Nevertheless, the dichotomous method is considered to have a weakness because the equal weight given for each item might result in a standard that has more disclosure items appearing to be more important than a standard with less disclosure items (Al-Shiab, 2003). For example, IAS1-Presentation of Financial Statements contains more disclosure items than IAS 2-Inventories; thus under the dichotomous method the IAS1 may appear more important than IAS2. To overcome this problem, several studies used the 'Partial Compliance (PC) unweighted approach' to measure the extent of compliance with accounting standards, such as Al-Shiab (2003), Street and Gray (2002) and Tsalavoutas et al. (2010). According to Al-Shiab (2003, p.223), the PC method "avoids the problem of unintentionally giving more weight to a standard with a large number of items in the index", and accordingly each standard appears to have equal weighting. This study also employs the PC unweighted approach as a robustness analysis. The scoring procedure of the PC method is similar with the dichotomous method, i.e. one, zero or NA (not applicable) for disclosure, non-disclosure or inapplicable items, respectively. Both the dichotomous and PC methods are unweighted disclosure indexes whereby all disclosure items are assumed to be equally important to all users of annual reports. The difference between the PC method and the dichotomous method lies in the computation of the total compliance scores, because, under the PC method, the ratio is computed by adding the extent of compliance for each standard. This sum is then divided by the total number of standards applicable to each company. ${ }^{5}$ The formula for the PC unweighted method is shown as follows:

$$
P C_{\mathrm{j}}=\frac{\sum_{i=1} X_{\mathrm{i}}}{R_{\mathrm{j}}}
$$

Where $\mathrm{PC}_{j}$ is the total compliance score for each company and $0 \leq \mathrm{PC}_{j} \leq$ $1 ; \mathrm{X}_{i}$ is the level of compliance with each standard; and $\mathrm{R}_{j}$ is the total number of applicable standards for each company $j$.

\subsection{Findings: Annual Report Analysis}

As shown in Table 1, using the dichotomous method, the average compliance scores by Malaysian public listed companies are $88 \%$, while the minimum and maximum compliance scores are $65.2 \%$ and $98 \%$, respectively. Whereas, using the PC method, the average compliance score is $84 \%$, and the minimum and

\footnotetext{
5 See Tsalavoutas et al. (2010) for the detailed discussion of the differences between the dichotomous method and the PC method.
} 
maximum compliance scores are $53 \%$ and $97 \%$, respectively. The findings show that the dichotomous method gives a higher compliance score than the PC method. This shows that only relying on one method to measure compliance scores would result in different perceptions about the level of compliance with mandatory disclosures in one country. Thus, using two methods to measure compliance scores may prevent reporting misleading or bias results.

Similar to prior studies (e.g. Glaum and Street, 2003; Cairns, 2001), the present study also finds that none of the examined companies received a qualified audit opinion with respect to non-compliance with IFRS disclosure requirements. The analysis of each accounting standard shows that the lowest compliance score is FRS136-Impairment of Assets (71.7\%; sd. 21.4\%), followed by FRS 117-Leases (73.5\%; sd. 23.4\%) and FRS 119-Employee Benefit (75.7\%; sd. $26.3 \%$ ). The standard deviations (sd.) of these accounting standards are also high, which suggests that there is considerable variation in the compliance scores for these standards. The results are shown in Table 2 in descending order of the average compliance scores. It is also observed that the minimum compliance score for FRS136, FRS117, FRS119, FRS114 and FRS2 is zero, which indicates that there are companies that do not provide any of the information required by these standards. Further investigation (refer results in Table 3 ) reveals that a considerable number of companies have compliance scores below 70\% for FRS119, FRS117

Table 1: Frequency and distribution of compliance scores $(\mathrm{N}=225)$

\begin{tabular}{|c|c|c|c|c|}
\hline & \multicolumn{2}{|c|}{ PC method } & \multicolumn{2}{|c|}{ Dichotomous method } \\
\hline Mean & \multicolumn{2}{|c|}{0.84} & \multicolumn{2}{|c|}{0.88} \\
\hline Median & \multicolumn{2}{|c|}{0.84} & \multicolumn{2}{|c|}{0.89} \\
\hline Minimum & \multicolumn{2}{|c|}{0.53} & \multicolumn{2}{|c|}{0.65} \\
\hline Maximum & \multicolumn{2}{|c|}{0.97} & \multicolumn{2}{|c|}{0.98} \\
\hline Standard Deviation (SD) & \multicolumn{2}{|c|}{0.07} & \multicolumn{2}{|c|}{0.05} \\
\hline Skewness & \multicolumn{2}{|c|}{-0.95} & \multicolumn{2}{|c|}{-1.06} \\
\hline Kurtosis & \multicolumn{2}{|c|}{1.42} & \multicolumn{2}{|c|}{1.40} \\
\hline Kolmogorov-Smirnov & \multicolumn{2}{|c|}{0.001} & \multicolumn{2}{|c|}{0.000} \\
\hline Shapiro-Wilk & \multicolumn{2}{|c|}{0.000} & \multicolumn{2}{|c|}{0.000} \\
\hline Paired sample t-test & \multicolumn{4}{|c|}{-16.441 *** } \\
\hline Wilcoxon test & \multicolumn{4}{|c|}{$-12.132 * * *$} \\
\hline Compliance Score Ranges & $N$ & $\%$ & $N$ & $\%$ \\
\hline $90 \%-100 \%$ & 52 & 23.1 & 108 & 48.0 \\
\hline $80 \%-89.9 \%$ & 126 & 56.0 & 100 & 44.5 \\
\hline $70 \%-79.9 \%$ & 38 & 16.9 & 16 & 7.1 \\
\hline $60 \%-69.9 \%$ & 7 & 3.1 & 1 & 0.4 \\
\hline $50 \%-59.9 \%$ & 2 & 0.9 & 0 & 0.0 \\
\hline$<50 \%$ & 0 & 0.0 & 0 & 0.0 \\
\hline Total & 225 & 100.0 & 225 & 100.0 \\
\hline
\end{tabular}


and FRS136, i.e. 84 companies, 74 companies and 60 companies, respectively. These findings suggest that most of the Malaysian companies have difficulty in complying with the FRS119-Employee Benefits, FRS117-Leases and FRS136Impairment of Assets.

Table 2: Frequency and distribution of compliance scores for each standard

\begin{tabular}{|l|c|c|c|c|c|c|}
\hline Standard & $\mathrm{N}$ & Mean & Median & Min & Max & Sd. \\
\hline $\begin{array}{l}\text { FRS101-Presentation of Financial } \\
\text { Statements }\end{array}$ & 225 & 0.96 & 0.97 & 0.87 & 1.00 & 0.03 \\
\hline $\begin{array}{l}\text { FRS 5 - Non-current Assets Held for } \\
\text { Sale and Discontinued Operations }\end{array}$ & 74 & 0.94 & 1.00 & 0.33 & 1.00 & 0.13 \\
\hline FRS116 - Property, Plant and Equipment & 225 & 0.93 & 1.00 & 0.46 & 1.00 & 0.11 \\
\hline FRS114 - Segment Reporting & 182 & 0.93 & 1.00 & 0.00 & 1.00 & 0.17 \\
\hline $\begin{array}{l}\text { FRS132 - Financial Instrument } \\
\text { Disclosure }\end{array}$ & 223 & 0.89 & 0.91 & 0.30 & 1.00 & 0.12 \\
\hline FRS2 - Share Based Payment & 92 & 0.83 & 0.88 & 0.00 & 1.00 & 0.17 \\
\hline FRS138 - Intangible Assets & 89 & 0.79 & 0.83 & 0.29 & 1.00 & 0.22 \\
\hline FRS140 - Investment Property & 115 & 0.78 & 0.83 & 0.40 & 1.00 & 0.13 \\
\hline FR 3 - Business Combination & 72 & 0.77 & 0.80 & 0.12 & 1.00 & 0.18 \\
\hline FRS119 - Employee Benefit & 225 & 0.76 & 0.80 & 0.00 & 1.00 & 0.26 \\
\hline FRS117 - Leases & 187 & 0.74 & 0.75 & 0.00 & 1.00 & 0.23 \\
\hline FRS136 - Impairment of Assets & 155 & 0.72 & 0.78 & 0.00 & 1.00 & 0.21 \\
\hline
\end{tabular}

Notes:

$\mathrm{N}=$ number of companies for which each standard was relevant; $\mathrm{Sd} .=$ standard deviation.

Table 3: Range of compliance scores for each standard

\begin{tabular}{|c|c|c|c|c|c|c|c|c|c|c|c|c|c|}
\hline \multirow{2}{*}{ Standard } & \multirow{2}{*}{\begin{tabular}{|l|}
$\%$ \\
$N$ \\
\end{tabular}} & \multicolumn{2}{|c|}{$\geq 90$} & \multicolumn{2}{|c|}{$80-89.9$} & \multicolumn{2}{|c|}{ 70- 79.9} & \multicolumn{2}{|c|}{ |60- 69.9} & \multicolumn{2}{|c|}{ |50- 59.9} & \multicolumn{2}{|c|}{$\mid<\mathbf{5 0}$} \\
\hline & & $\mathbf{N}$ & $\%$ & $\mathbf{N}$ & $\%$ & $\mathbf{N}$ & $\%$ & $\mathbf{N}$ & $\%$ & $\mathbf{n}$ & $\%$ & $\mathbf{n}$ & $\%$ \\
\hline \begin{tabular}{|l|} 
FRS101 \\
\end{tabular} & 225 & 214 & 95.1 & 11 & 4.9 & - & 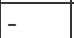 & - & - & - & - & - & - \\
\hline FRS5 & 74 & 60 & 81.1 & 4 & 5.4 & 7 & - & 9 & 12.2 & 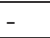 & 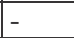 & 1 & 1.4 \\
\hline FRS116 & 225 & 159 & 70.7 & 32 & 14.2 & 25 & 11.1 & 7 & 3.1 & 1 & 0.4 & 1 & 0.4 \\
\hline FRS114 & 182 & 141 & 77.5 & 25 & 13.7 & 9 & 4.9 & - & & 1 & 0.5 & 6 & 3.3 \\
\hline \begin{tabular}{|l|} 
FRS132 \\
\end{tabular} & 223 & 124 & 55.6 & 59 & 26.5 & 27 & 12.1 & 9 & 4.0 & 3 & 1.3 & 1 & 0.4 \\
\hline \begin{tabular}{|l|} 
FRS2 \\
\end{tabular} & 92 & 30 & 32.6 & 29 & 31.5 & 24 & 26.1 & 5 & 5.4 & 1 & 1.1 & 3 & 3.3 \\
\hline FRS138 & 89 & 32 & 36.0 & 31 & 34.8 & 2 & 2.2 & 4 & 4.5 & 6 & 6.7 & 14 & 15.8 \\
\hline \begin{tabular}{|l|} 
FRS140 \\
\end{tabular} & 115 & 18 & 15.7 & 58 & 50.4 & 16 & 13.9 & 15 & 13.0 & 3 & 2.6 & 5 & 4.3 \\
\hline FRS3 & 72 & 27 & 37.5 & 16 & 22.2 & 11 & 9.7 & 7 & 9.7 & 7 & 9.7 & 4 & 5.6 \\
\hline FRS11 & 225 & 103 & 45.8 & 11 & 4.9 & 25 & 5.3 & 12 & 5.3 & 53 & 23.6 & 21 & 9.4 \\
\hline FRS11 & 187 & 50 & 26.7 & 22 & 11.8 & 51 & 16.1 & 30 & 16.0 & 11 & 5.9 & 23 & 12.3 \\
\hline \begin{tabular}{|l|} 
FRS136 \\
\end{tabular} & 155 & 26 & 16.8 & 50 & 32.3 & 19 & 18.1 & 28 & 18.1 & 10 & 6.5 & 22 & 14.2 \\
\hline
\end{tabular}

Notes:

$\mathrm{N}=$ number of companies for which each standard was relevant 


\section{Findings: Interviews}

As mentioned earlier, interviews with financial controllers and auditors were conducted in order to understand why there was a lack of compliance with FRS136, FRS117 and FRS119 by most of the Malaysian companies. The findings from the interviews suggest several factors that contribute to non-compliance with FRS136. The most cited reason by interviewees was that compliance with this standard would be to the detriment of the company's performance because the impairment of assets affects the company's profit. Another reason is related to the increment in the cost of compliance because companies need to engage with evaluators to value their assets in order to comply with the standard. In addition, one of interviewees believesd that the norms of business practices in Malaysia also contribute to non-compliance with the standard. This is because in order to comply with FRS136, the company must prepare forward-looking cash flow statements for a minimum of up to five years, which is not the practice of most of the Malaysian companies.

With regard to FRS117-Leases, interviewees argue that a lack of compliance with this standard could be due to the ignorance of the prepares of its disclosure requirements, who perceived that the information is not useful and would not be read by users of financial statements. As for FRS119-Employee Benefits, interviewees believe that a lack of compliance with this standard could be because certain companies consider information relating to remuneration and benefits to employees and key management personnel as sensitive. Another reason is related to the cost of compliance because companies need to engage with actuarial experts to value its defined benefit plan assets. The interviewees also argue that certain disclosures under FRS119 are perceived as irrelevant to users and that this could also contribute to non-compliance with the standard.

\section{Conclusion}

This study has documented that, on average, the level of compliance with IFRS in Malaysia was $88 \%$ (dichotomous method) or $84 \%$ (PC method), and that none of the Malaysian listed companies fully complies with IFRS. Irrespective of the measurement methods used, we find that none of the companies examined received a qualified audit opinion despite their significant non-compliance with IFRS disclosure requirements. It is also documented that most of the Malaysian companies have a problem complying with FRS136-Impairment of Assets, FRS117-Leases and FRS119-Employee Benefit. Interviews with financial controllers and auditors reveal that the factors of non-compliance with these standards could be due to high compliance costs (related to FRS136 and FRS119), ignorance of disclosure requirements by the preparers (FRS117), certain disclosures are perceived as irrelevant to users (FRS117 and FRS119), norms in the business practice (FRS136), and sensitivity of certain information like staff remuneration and benefits (FRS119). 
At least two inferences can be made from the findings above. First, regardless of the evidence of significant non-compliance with IFRS disclosure requirements of Malaysian listed companies, they still receive clean audit reports from auditors. This indicates that not only is there a lack of transparency in the Malaysian financial reporting, it also suggests the ineffectiveness of the present system for regulatory enforcement in curbing non-compliance with IFRS in Malaysia. Compliance with accounting standards in Malaysia is mandated in the Companies Act 1965 and the enforcement of compliance is also prescribed under the Financial Reporting Act 1997. Nevertheless, the findings of this study may support the contentions made in prior studies (e.g. Zhuang et al., 2000; Tam and Tan, 2007) that, although the regulations in Malaysia appear to be clearly written in law, they are ineffective in terms of enforcement.

Second, the findings demonstrate that the adoption of high quality accounting standards like IFRS does not necessarily lead to high quality financial reporting or to an increase in transparency. This is because many factors influence the incentives of financial reporting especially when enforcement is lax. In the absence of stringent enforcement mechanisms, the companies might treat mandatory disclosure in the same way as voluntary disclosure, as they know that they will not be subjected to severe punishment for breaching the law (Al-Akra et al., 2010; Zeff, 2007). As Hope (2003, p. 238) argues "if nobody takes actions when rules are breached, the rules remain requirements only on paper."

The findings of this study may not only be of interest and useful for regulators and policymakers in Malaysia but also to other countries that intend to adopt or have already adopted IFRS. The findings discussed above can be used to improve the level of compliance with IFRS and to strengthen compliance with enforcement. The necessary action must be taken by the relevant authorities so that the effectiveness or benefits of IFRS can be realized.

\section{References}

Al-Akra, M., Eddie, I. A. and Ali, M. J. (2010). 'The influence of the introduction of accounting disclosure regulation on mandatory disclosure compliance: Evidence from Jordan.' British Accounting Review, 42(3): 170-186.

Al-Shammari, B., Brown, P., and Tarca, A., (2008). 'An Investigation of Compliance with International Accounting Standards by Listed Companies in the Gulf Co-Operation Council Member States.' International Journal of Accounting, 43: 425-447.

Al-Shiab, M. (2003). Financial consequences of IAS Adoption: The case of Jordan. Unpublished PHD thesis, University of New Castle Upon Tyne.

Ali, M.J, Ahmed, K. and Henry, D. (2004). 'Disclosure compliance with national accounting standards by listed companies in South Asia.' Accounting and Business Research, 34(3): 183-199. 
Barth, M. E., Landsman, W. R. and Lang, M. H. (2008). 'International Accounting Standards and Accounting Quality.' Journal of Accounting Research, 46 (3): 467-498.

Brown, P. (2011). 'International Financial Reporting Standards: what are the benefits?' Accounting and Business Research, 41(3): 269-285

Brown, P. and Tarca, A. (2007). 'Achieving High Quality, Comparable Financial Reporting: A review of Independent Enforcement Bodies in Australia and the United Kingdom.' Abacus, 43(4): 438-465.

Cairns, D. (2001). 'International accounting standards survey 2000: an assessment of the use of IAS in the financial statements of listed companies.' David Cairns International Financial Reporting, Henley on Thames.

Cooke, T.E., (1989). 'Disclosure in the Corporate Annual Reports of Swedish Companies.' Accounting and Business Research, 19(74):113-124.

Cooke, T.E., (1992). 'The Impact of Size, Stock Market Listing and Industry Type on Disclosure in the Annual Reports of Japanese Listed Corporations.' Accounting and Business Research, 22 (87): 229-237.

Deloitte (2006). 'Implementing Financial Reporting Standards - The challenges for 2006.' Kuala Lumpur: Deloitte Malaysia

Glaum, M., and Street, D. (2003). 'Compliance with the Disclosure Requirements of Germany’s New Market: IAS versus US GAAP.' Journal of International Financial Management and Accounting, 14(1): 64-100.

Hodgdon, C., Tondkar, R. H., Adhikari, A. and Harless, D. W. (2009). 'Compliance with International Reporting Standards and auditor choice: New evidence on the importance of the statutory audit.' International Journal of Accounting, 44:33-55.

Hope, $O-K$. (2003). 'Disclosure Practices, Enforcement of Accounting Standards, and Analysts' Forecast Accuracy: An International Study.' Journal of Accounting Research, 41(2): 235-272.

La Porta, R., Lopez-de-Silanes, F., Shleifer, A. and Vishny, R.W. (1998). 'Law and finance.' Journal of Political Economy, 106:1113-1155.

Liew, P. K. (2007). 'Corporate Governance Reforms in Malaysia: the key leading players' perspectives.' Corporate Governance: An International Review, 15(5):724-740.

Marston, C. L. and Shrives, P. J. (1991). 'The use of disclosure indices in accounting research: A Review Article.' British Accounting Review, 23:195-210.

Owusu-Ansah, S. (1998). 'The Impact of Corporate Attributes on the extent of Mandatory Disclosure and Reporting by Listed Companies in Zimbabwe.' International Journal of Accounting, 33(5): 605-631.

Owusu-Ansah, S. and Yeoh, J. (2005). 'The effect of legislation on corporate disclosure practices.' Abacus, 41(1): 92-109.

Saudagaran, S. M. (2001). 'International Accounting: A User Perspective,' SouthWestern College Publishing. 
Saudagaran, S. M. \& Diga, J. G. (1997). 'Financial reporting in emerging capital markets: characteristics and policy issues.' Accounting Horizons, 11(2): 41-64.

Saudagaran, S. M. and Diga, J. G. (2000). 'The International Environment of Financial Reporting Regulation in ASEAN.' International Journal of Accounting, 35(1):1-26.

Sekaran, U. (2003). 'Research methods for business (4th Ed.).' Hoboken, NJ: John Wiley \& Sons.

Street, D.L. and Gray, S. (2002). 'Factors influencing the extent of corporate compliance with International Accounting Standards: summary of research monograph.' Journal of International Accounting, Auditing \& Taxation, 11: 51-76.

Street, D.L. and Bryant, S.M. (2000). 'Disclosure level and Compliance with IASs: A comparison of companies with and without U.S. listings and filings.' International Journal of Accounting, 35(3): 305-329.

Street, D.L., Gray, S.J., and Bryant, S.M. (1999). 'Acceptance and Observance of International Accounting Standards: An Empirical Study of Companies Claiming to Comply with IASs.' International Journal of Accounting, 34(1):11-48.

Tam, O.K. and Tan, M.G. (2007). 'Ownership, governance and firm performance in Malaysia.' Corporate Governance: An International Review, 15(2): 208-222.

Tsalavoutas, I. (2011). 'Transition to IFRS and compliance with mandatory disclosure requirements: What is the signal?' Advances in Accounting, incorporating Advances in International Accounting, 27:390-405.

Tsalavoutas, I., Evans, L. and Smith, M. (2010). 'Comparison of two methods for measuring compliance with IFRS mandatory disclosure requirements.' Journal of Applied Accounting Research, 11(3): 213-228.

Tsalavoutas, I. (2009). 'The adoption of IFRS by Greek listed companies: financial statement effects, level of compliance and value relevance.' Unpublished $\mathrm{PhD}$ thesis, University of Edinburgh.

Yeoh, J. (2005). 'Compliance with mandatory disclosure requirements by New Zealand Listed Companies.' Advances in International Accounting, 18: 245-262.

Zeff, S. A. (2007). 'Some obstacles to global financial reporting comparability and convergence at a high level of quality.' British Accounting Review, 39: 290-302.

Zhuang, J., Edwards, D., Webb, D. And Capulong, V.A. (2000). 'Corporate governance and finance in East Asia: A study of Indonesia, Republic of Korea, Malaysia, Philippines and Thailand: Volume One (A consolidated report)', The Asian Development Bank, Manila. 